\title{
Two new species of Pseudaetobatus Cappetta, 1986 (Batoidei: Myliobatidae) from the southeastern United States
}

\author{
David J. Cicimurri and Jun A. Ebersole
}

\begin{abstract}
Two new species of the myliobatid ray Pseudaetobatus Cappetta, 1986 are described from Eocene localities in three different states within the southeastern United States. Pseudaetobatus belli sp. nov. was recovered from south Alabama and southeast Mississippi from units within the lower Eocene portion of the Tallahatta Formation, as well as older strata of the underlying Hatchetigbee Formation. This species differs from the type species, $P$. casieri Cappetta, 1986, in that teeth are larger in overall size, and distal-most lateral teeth are less wide and have a shorter, less pronounced distal projection but more sharply basally curved margin. Pseudaetobatus undulatus sp. nov. occurs within the upper Eocene Dry Branch Formation of south-central South Carolina, and this species is easily distinguished from $P$. casieri and $P$. belli sp. nov. by distal-most lateral teeth that are conspicuously sinuous in labial and lingual views. In addition to possessing features unique to each species, both $P$. belli sp. nov. and $P$. undulatus sp. nov. possess an additional lateral tooth morphology that is unknown in the type species. These new specimens significantly extend the paleogeographic distribution of Pseudaetobatus, and the genus is now known to occur virtually throughout the entire Eocene.
\end{abstract}

David J. Cicimurri [dave.cicimurri@scmuseum.org], South Carolina State Museum, 301 Gervais Street, Columbia 29201, USA

Jun A. Ebersole [jebersole@mcwane.org], McWane Science Center, $20019^{\text {th }}$ Street North, Birmingham, Alabama 35203, USA

Keywords: Myliobatidae; new species; Eocene; South Carolina; Alabama; Mississippi

\section{INTRODUCTION}

Pseudaetobatus Cappetta, 1986 is an extinct myliobatid ray that occurs in lower Eocene (Ypresian) deposits of Morocco, middle Eocene (Lutetian) strata of Angola, and late Eocene sediments in Egypt (Underwood et al., 2011; Darteville and Casier, 1959; Cappetta, 1986). The genus has generally not been recognized outside of Africa but might occur in middle-to-late Eocene strata of France (Duthiel, 1991). Only a single species, $P$.

http://zoobank.org//71918C81-C8B4-4B5F-B70E-AEF746475819

PE Article Number: 18.1.15A

Copyright: Palaeontological Association March 2015

Submission: 19 November 2014. Acceptance: 7 March 2015

Cicimurri, David J. and Ebersole, Jun A. 2015. Two new species of Pseudaetobatus Cappetta, 1986 (Batoidei: Myliobatidae) from the southeastern United States. Palaeontologia Electronica 18.1.15A: 1-17.

palaeo-electronica.org/content/2015/1114-new-eocene-rays-from-the-u-s 


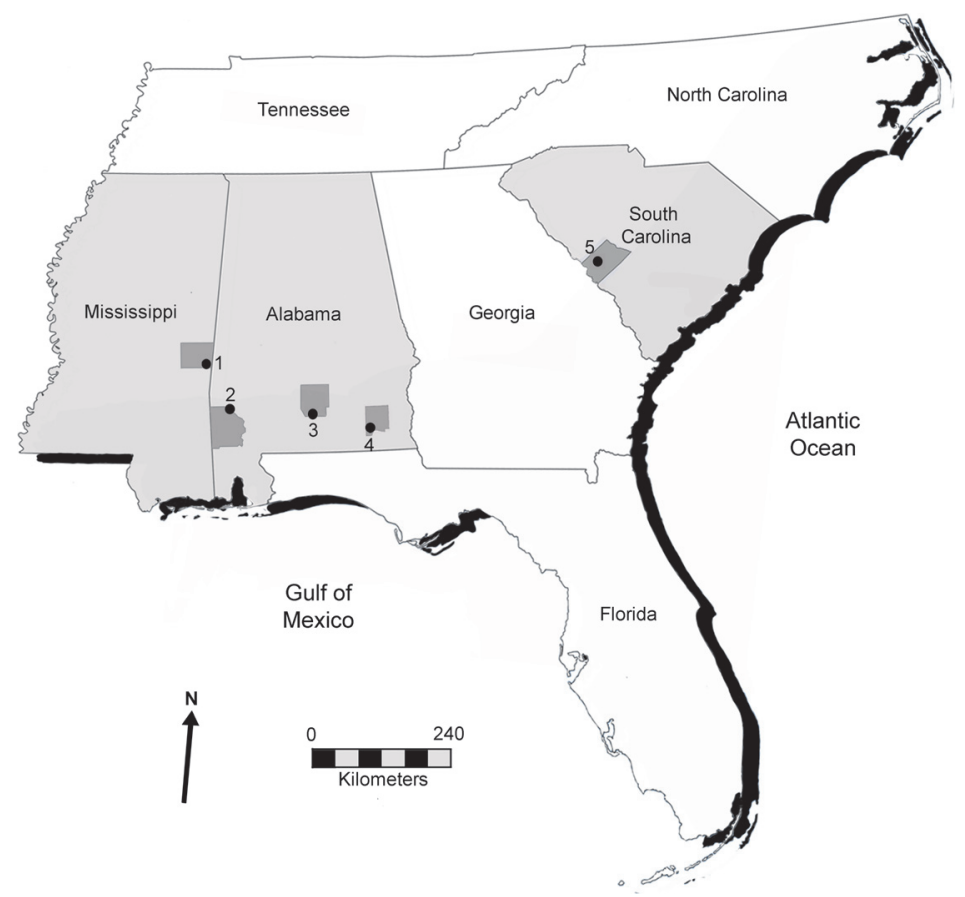

FIGURE 1. Generalized geographic map of the southeastern United States, with counties from which Pseudaetobatus teeth were recovered (highlighted in light gray). Specific localities indicated by black dots. 1, Whynot locality, Lauderdale County, MS; 2, site AWa-1, Washington County, AL; 3, site ABu-3, Butler County, AL; 4, site ADI-1, Dale County (type locality Pseudaetobatus belli), AL; 5, Dry Branch localities, Aiken County, SC.

casieri Cappetta, 1986, has been described. Herein we document two new species of Pseudaetobatus that were collected from Eocene strata of the Gulf and Atlantic coastal plains of the United States (Figure 1). Gulf Coast specimens were primarily derived from lower Eocene deposits of the Tallahatta Formation of Dale County, Alabama, including the basal Meridian Sand Member and a fossiliferous stratum slightly higher in the section. Incomplete specimens from the uppermost part of the lower Eocene Hatchetigbee Formation (underlying the Tallahatta) in Butler and Dale counties, Alabama, and Lauderdale County, Mississippi, represent the oldest North American records of Pseudaetobatus. The Atlantic Coast material was collected from two exposures of the upper Eocene Dry Branch Formation in Aiken County, South Carolina. The purpose of this report is to formally describe these new species, discuss the organization of the teeth within the dentition, and comment on the paleobiogeographic and temporal significance of these new taxa.

\section{STRATIGRAPHIC FRAMEWORK}

\section{Hatchetigbee Formation}

The Hatchetigbee Formation specimens discussed herein were all recovered from an upper unnamed member of the formation from three distinct localities in Alabama and Mississippi: site ABu-3 in Butler County, AL; site AWa-1 in Washington County, $\mathrm{AL}$; and the Whynot locality located in Lauderdale County, MS (Figure 1; more detailed geographic information on these localities is provided in the Systematic Paleontology section).

In both states, the Hatchetigbee comprises the upper unit of the upper Paleocene-to-lower Eocene Wilcox Group. In Alabama, the thickness of the Hatchetigbee ranges from $76 \mathrm{~m}$ in the western part of the state to $11 \mathrm{~m}$ in the east, and the formation is subdivided into two members, the lower Bashi Marl and an unnamed upper member (Mancini and Tew, 1995; Raymond et al., 1988; Toulmin, 1977). In Mississippi, the Bashi sequence is more complete than in Alabama and is considered a distinct formation from the Hatchetigbee (Dockery et al., 1994).

Both the Hatchetigbee in Mississippi and the corresponding unnamed upper member in Alabama are composed of a series of non-marine and 


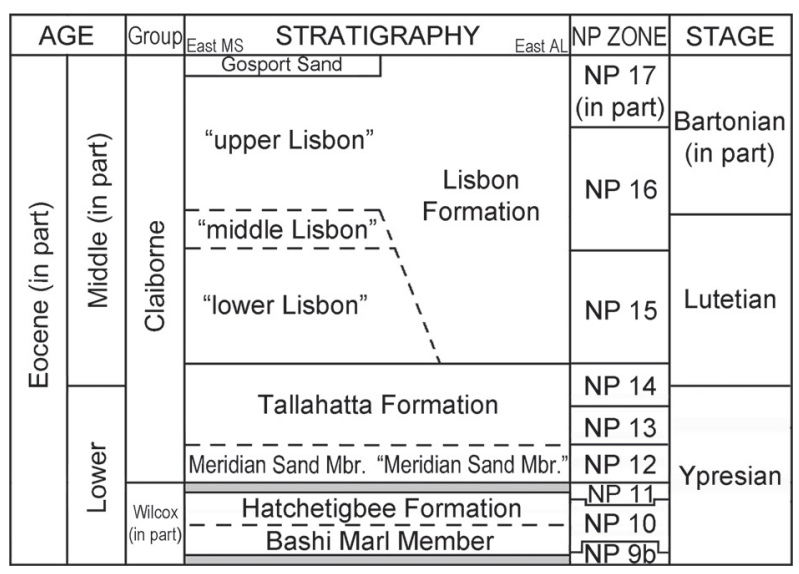

FIGURE 2. Chronostratigraphy, lithostratigraphy, and biostratigraphy of lower-to-middle Eocene strata of eastern Mississippi and Alabama. Modified from Bybell and Gibson (1985).

marine beds that consist of olive green finegrained, micaceous and carbonaceous fossiliferous sand, with silty clay, silt, and sandy clay (Raymond et al., 1988; Toulmin, 1977). Bounded by unconformities both above and below, the Hatchetigbee is interpreted to represent a TAGC-2.4 type 1 depositional sequence, and strata represent inner neritic deposits (Gibson, 1982; Mancini and Tew, 1990; 1995).

Previous investigations of the biostratigraphy of the Hatchetigbee Formation in Alabama have determined that the upper unnamed member formed during the upper part of calcareous nannoplankton zone (NP) 10, and continued throughout the duration of NP 11 (Mancini and Tew, 1995). The specimens recovered from the Whynot locality in Lauderdale County, Mississippi were collected from $1.2 \mathrm{~m}$ below the contact with the overlying Tallahatta Formation suggesting they fall exclusively within NP 11. The identification of these calcareous nannofossil zones suggests the age of the Hatchetigbee specimens to be lower-to-middle Ypresian.

\section{Tallahatta Formation}

The Tallahatta Formation specimens presented in this study, which includes the type material of a new Pseudaetobatus species, were collected from site ADI-1 in Dale County, southeast Alabama (Figure 1; more detailed geographic information is provided in the Systematic Paleontology section). In Alabama, the Tallahatta Formation represents the basal unit of the lower-to-middle Eocene Claiborne Group. In ascending order, this group is composed of the Tallahatta, Lisbon, and Gosport Sand formations (Raymond et al., 1988).
The contact between the Claiborne Group and the underlying Wilcox Group represents a type 1 unconformity, which lies at the contact between the Tallahatta and underlying Hatchetigbee Formation (Bybell and Gibson, 1985; Mancini and Tew, 1991).

The aerial extent of the Tallahatta Formation forms an arcuate belt that extends through northern and central Mississippi, east to west across southern Alabama, and into western Georgia. In Mississippi, the Tallahatta Formation is divided into three members: the Meridian Sand, Basic City Shale, and Neshoba Sand. Although outcrops of the basal Meridian Sand are exposed in southwestern Alabama (Bybell and Gibson, 1985), the Tallahatta thins in the southeastern part of the state and is generally not differentiated into members (Raymond, 1988; Savrda et al., 2010). Bybell and Gibson (1985), however, described a unit at the base of the Tallahatta in southeastern Alabama that they referred to as "Meridian Sand equivalent."

The lithology of the Tallahatta Formation varies both vertically and laterally in Alabama (Bybell and Gibson, 1985, Savrda et al., 2010). The Tallahatta samples examined in this study were collected in the early 1980s from two distinct lithologic units within the exposed section at site ADI-1 (Figure 2). One small sample (>0.5 kg) was likely collected from the lower part of the formation as it is composed of fine gray, fossiliferous, gravelly, lignitic sand. These lithologic characteristics are unique to the "Meridian Sand equivalent" beds described by Bybell and Gibson (1985). Additional samples $(\sim 27 \mathrm{~kg})$, which included the type material of a new Pseudaetobatus species, were likely collected from just above these basal Tallahatta beds and are composed of a coarse sand and gravel, glauconitic sand, and claystone. The lithology and abundance of invertebrates that are often bound in calcareous matrix are common characteristics of the Tallahatta beds that overlie the Meridian Sand (Bybell and Gibson, 1985; Raymond et al., 1988). Overall, the Tallahatta is thought to represent a single third-order depositional sequence (sequence TE2.1 of Baum and Vail, 1988; Mancini and Tew, 1991), with the lower part of the unit consisting of nearshore and shallow marine deposits, and the upper half deeper, inner shelf deposits (Bybell and Gibson, 1985).

In an attempt to determine the precise age of the Tallahatta type material, various matrix samples from site ADI-1 were sent to the U.S. Geological Survey in Reston, VA and the Geological Survey of Alabama in Tuscaloosa, to be examined for the presence of nanno- and micro-fossils. 


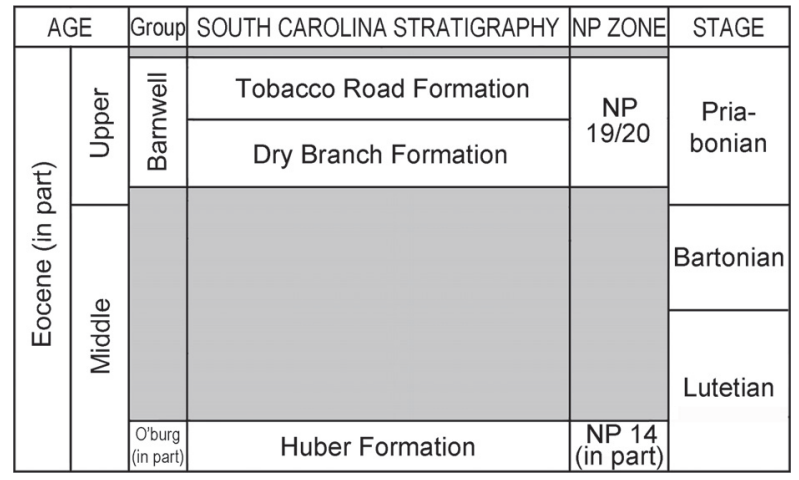

FIGURE 3. Chronostratigraphy, lithostratigraphy, and biostratigraphy of middle-to-upper Eocene strata of south-central South Carolina. Abbreviation: O'burg = Orangeburg.

Unfortunately, the samples were barren of calcareous nannoplankton (L. Bybell, pers. comm.), and although both planktonic and benthic foraminifera were present, they were exposed to too much dissolution to be identified beyond the family level ( $\mathrm{S}$. Ebersole, pers. comm.). However, previous investigations of the biostratigraphy of the Tallahatta in Alabama have concluded that the basal Meridian Sand and equivalent beds are entirely confined within NP 12 (Bybell and Gibson, 1985; Mancini, 2008), placing the unit within the middle-to-upper Ypresian. In eastern Alabama, Bybell and Gibson (1985) mapped the Tallahatta to a thickness of up to $23 \mathrm{~m}$. With the bulk of the samples being collected from just above the basal "Meridian Sand equivalent" beds, it is likely the type material of the new Pseudaetobatus species falls within NP 13 and is upper Ypresian in age.

\section{Dry Branch Formation}

The South Carolina specimens were collected from the upper Eocene Dry Branch Formation in Aiken County in the south-central part of the state (Figure 1). The Dry Branch Formation is part of the Barnwell Group, and three members have been recognized, including the Griffins Landing Sand, Twiggs Clay, and Irwinton Sand (see Huddleston and Hetrick, 1979). The stratigraphic relationships between these members are complex, and the differing sediments attributed to these members can represent contemporaneous deposition in widely separated areas (seen in the field as intertonguing lateral facies changes; see Huddleston and Hetrick, 1986). For example, Twiggs Clay-type lithologies have been reported to occur in the Griffins Landing and Irwinton sands (Eversull, 2005; Huddleston and Hetrick, 1979). Identification of these upper Eocene units within Georgia is facilitated by exposures of relatively thick and fossiliferous sections, but identifying and correlating strata in South Carolina has been hampered by lack of thick exposures, and those that can be examined are often highly weathered and devoid of fossils (i.e., Huddleston, 1982).

In Aiken County, the Dry Branch Formation disconformably overlies kaolin deposits (which are up to $12.5 \mathrm{~m}$ thick) of the lower-to-middle Eocene Huber Formation (Figure 3). The contact between these two formations has been reported as a sequence boundary, and the base of the Dry Branch Formation consists of a lag deposit (Harris et al., 2002; Schroeder et al., 2002) that formed during the initial transgression of the Jackson Sea into the region (Huddleston, 1993; Huddleston and Hetrick, 1986).

The Dry Branch Formation is at least $28 \mathrm{~m}$ thick in Aiken County, and Twiggs Clay, Griffins Landing Sand, and Irwinton Sand lithologies have been reported in the area (Mittwede, 1982; Nystrom and Willoughby, 1982; Zullo and Kite, 1985). To the south of Aiken in the Jackson quadrangle, Mittwede (1982) described mustard-yellow to orange-yellow loose, fine-to-medium grained quartz sand containing thin, discontinuous clay beds that he attributed to the Irwinton Sand, and he noted that the unit thickened markedly towards the Aiken area. The Dry Branch Formation deposit yielding Pseudaetobatus teeth is consistent with the Irwinton Sand, and the stratum occurs approximately $2.0 \mathrm{~m}$ below the contact with the overlying Tobacco Road Formation.

Various barnacles and echinoderms occurring within the Dry Branch Formation and other Barnwell Group strata in South Carolina have been used to assign an upper Eocene, Priabonian age (Jacksonian) to the deposits (Carter, 1987; Huddleston, 1982; Nystrom and Willoughby, 1982; Steele et al., 1986; Zullo and Kite, 1985). Huddleston and Hetrick (1986) placed the Twiggs Clay sensu stricto of the Dry Branch Formation within NP 19/20, and this is corroborated by tektites (georgiaites) that have been recovered from the Dry Branch Formation in Georgia (i.e., Albin, 1999; Albin and Wampler, 1996; Harris et al., 2002; Schroeder et al., 2002). The tektites formed during the Chesapeake Bay Impact event and have a laser fusion age of approximately 34.5 m.y. (Povenmire and Povenmire, 2002). The Dry Branch Formation is therefore temporally equivalent to the Parkers Ferry Formation of the outer coastal plain of South Carolina (Dorchester County), which was 
also deposited within zone NP 19/20 (Edwards et al., 1997; Edwards et al., 2000; Falls and Prowell, 2001; Willoughby et al., 1999).

\section{METHODS AND MATERIAL}

The fossils discussed in this report were largely collected through processing bulk matrix ( $100 \mathrm{~kg}$ ), but some specimens were recovered as float directly adjacent to exposures, and some teeth from the Dry Branch Formation were acquired through donation. In the laboratory, bulk matrix was disaggregated in water and gently rinsed through USA Standard Testing Sieves down to $0.25 \mathrm{~mm}$ (\# 60 screen). The median teeth were often recovered broken, but many were successfully reassembled using thin butvar (B-76 in acetone) or cyanoacrylate. For taxa within Myliobatidae, the terms "symphyseal" (Herman et al., 2000), "medial" (Purdy et al., 2001), and "median" (Cappetta, 2012) have been used to identify teeth within the row that straddles the jaw symphysis. In this study we follow Cappetta (2012) in calling this the median row.

\section{Institutional Abbreviations}

MSC, McWane Science Center, Birmingham, Alabama; SC, South Carolina State Museum, Columbia.

\section{SYSTEMATIC PALEONTOLOGY}

Class CHONDRICHTHYES Huxley, 1880 Order MYLIOBATIFORMES Compagno, 1973

Family MYLIOBATIDAE Bonaparte, 1838

Genus PSEUDAETOBATUS Cappetta, 1986

Type species. Pseudaetobatus casieri Cappetta, 1986, lower Eocene (Ypresian) phosphate deposits, Sidi Daoui, Morocco.

\section{Pseudaetobatus belli sp. nov. Figures 4-5}

\section{zoobank.org/EFBD51F0-301D-4934-826B-4277524A0C86}

Etymology. Species named for Gorden L. Bell, Jr. in honor of his contributions to Alabama vertebrate paleontology. Gorden also collected the matrix sample from which this new species was recovered.

Hypodigm. MSC 35048 (holotype), lower median tooth (Figure 4.1); MSC 35054 (paratype), lower right distal-most lateral tooth (Figure 4.2); MSC 35058 (paratype), right half of upper? median tooth (Figure 4.5), MSC 35059 (paratype), upper right distal-most lateral tooth (Figure 4.3); MSC 35062 (paratype), intermediate lateral tooth (Figure 4.4). All Tallahatta Formation, site ADI-1.

Type locality. Site ADI-1, 31.317309 N, -85.71598 W (N 31 19' 02" lat., W 85 42' 57" long.), Dale County, Alabama.

Type horizon. Lower Tallahatta Formation, just above the "Meridian Sand Member equivalent" beds.

Additional material. Site ABu-3; 31.575983 N, 86.738533 W; Butler County, AL; Hatchetigbee Formation (NP 11) - MSC 12692, distal part of upper left median tooth; MSC 12695, median tooth fragment; MSC 35083, 13 tooth fragments; MSC 35078 , distal end of median tooth (Figure 5.2). Site AWa-1; 31.658767 N, -88.091680 W; Washington County, AL; Hatchetigbee Formation (NP 11) MSC 12699.1, left half of upper median tooth (Figure 5.1); MSC 12699.2, median tooth fragment; MSC 12670, fragments of three median teeth; MSC 12672, distal end of median tooth. Whynot Locality; 32.275506 N, -88.470072 W; Lauderdale County, MS; Hatchetigbee Formation (NP 11) - MSC 12756, distal end of median tooth; MSC 12776, distal-most lateral tooth (Figure 5.9). Site ADI-1; Dale County, AL, Meridian Sand Member; Tallahatta Formation (NP 12) - MSC 35079, right half of lower median tooth (Figure 5.13); MSC 35080, half of lower median tooth (Figure 5.10); MSC 35081, half of median tooth (Figure 5.4); MSC 35082, half of median tooth. Site ADI-1; Dale County, AL; Tallahatta Formation (NP 13) - MSC 35049, small lower median tooth (Figure 5.5); MSC 35050, small lower median tooth (Figure 5.7); MSC 35051, right half of large lower median tooth; MSC 35052 , left half of large lower median tooth (Figure 5.15); MSC 35053, middle portion of lower median tooth; MSC 35055 lower right distal-most lateral tooth (Figure 5.3); MSC 35056, lower right distalmost lateral tooth (Figure 5.11); MSC 35057, two distal-most lower lateral teeth; MSC 35060, upper right distal-most lateral tooth (Figure 5.12); MSC 35061, upper right distal-most lateral tooth (Figure 5.8); MSC 35063, 13 median tooth fragments; MSC 35064, 123 median tooth fragments; MSC 35065, incomplete lower median tooth (Figure 5.14); MSC 35066 incomplete lower median tooth; MSC 35067, incomplete lower median tooth; MSC 35068, incomplete lower median tooth; MSC 35069, incomplete lower median tooth; MSC 35070, incomplete lower median tooth; MSC 35071, left side of lower median tooth (Figure 5.6); MSC 35072, upper median tooth (probably from leading edge of dentition); MSC 35073, left half of upper median tooth; MSC 35074, left half of upper 


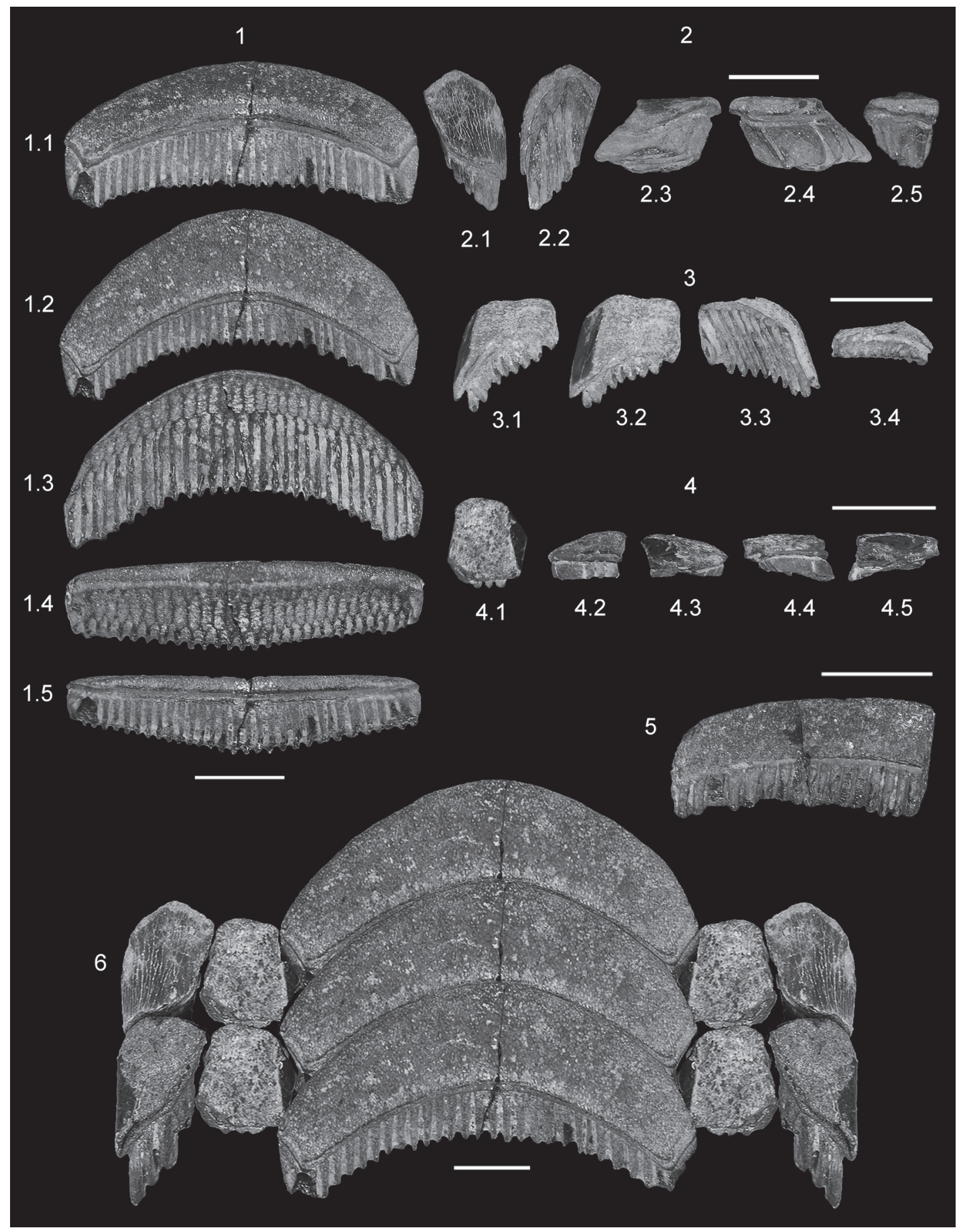

FIGURE 4. Pseudaetobatus belli sp. nov. hypodigm from the type stratum within the lower Eocene (NP 13) Tallahatta Formation, Dale County, Alabama. 1, MSC 35048, lower median tooth, oblique lingual (1.1), occlusal (1.2), basal (1.3), labial (1.4), and lingual (1.5) views. 2, MSC 35054, lower right distal-most lateral tooth, occlusal (2.1), basal (2.2), distal (2.3), mesial (2.4), and labial (2.5) views. 3, MSC 35059, upper right distal-most lateral tooth, oblique lingual (3.1), occlusal (3.2), basal (3.3), and labial (3.4) views. 4, MSC 35062, intermediate lateral tooth, occlusal (4.1) (labial at top), lingual (4.2), labial (4.3), mesial (4.4), and distal (4.5) views. 5, MSC 35058, partial upper? median tooth, occlusal view. 6, Occlusal view of hypothetical reconstruction of part of the lower dentition. This consists of specimens shown in 1 (MSC 35048), 2 (MSC 35054), 4 (MSC 35062), and Figure 5.3 (MSC 35055). 2, 4, and Figure 5.3 were reduced in size to be consistent with 1.4 was replicated and reversed to represent the left and right tooth rows. 2 and Figure 5.3 are from the right side but were reversed to represent the left side. The resulting composite series was then replicated. Scale bars equal $1.0 \mathrm{~cm}$. 


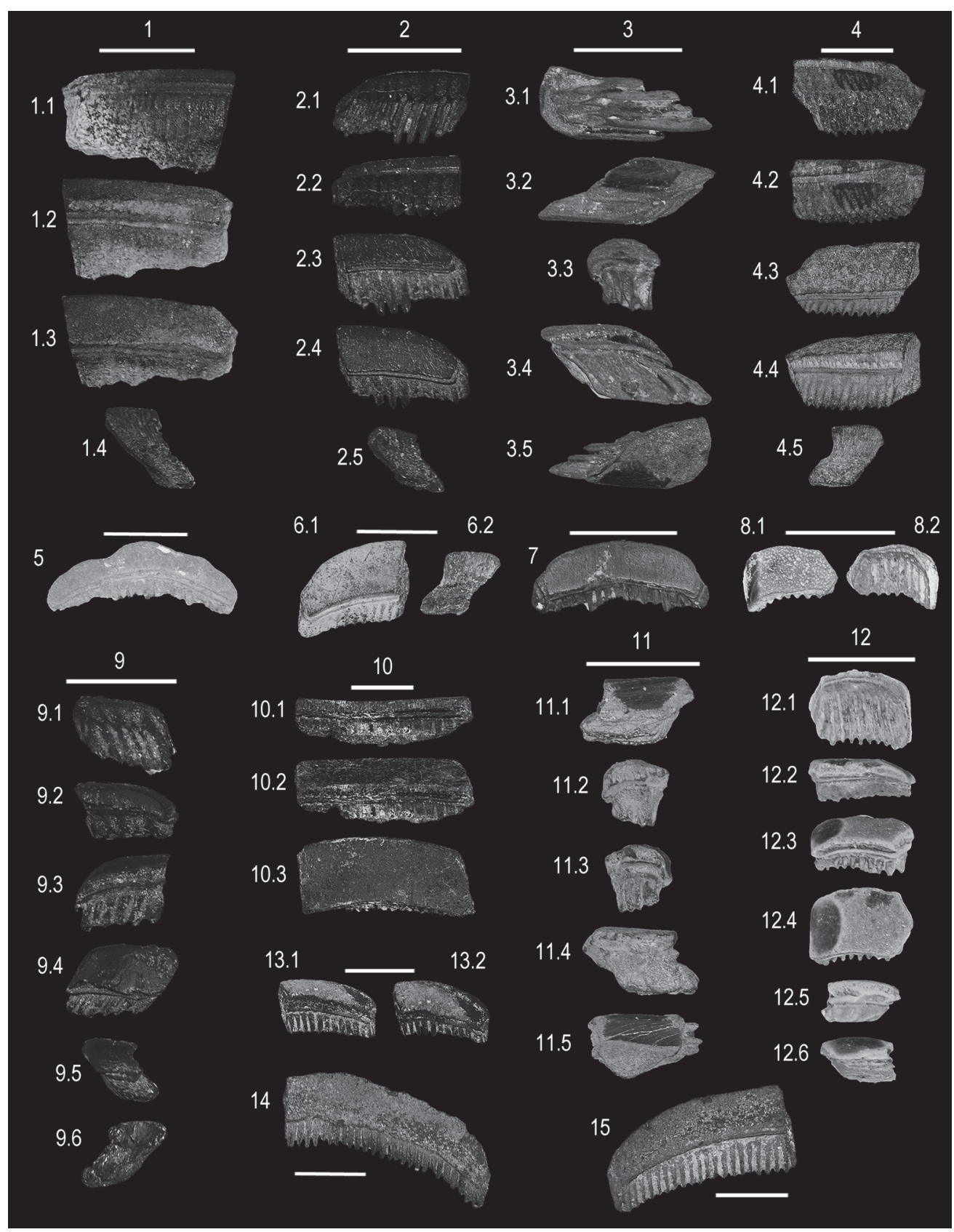

FIGURE 5. Pseudaetobatus belli sp. nov. from lower Eocene strata of Alabama and Mississippi. 1, MSC 12699.1, partial upper median tooth, baso-labial (1.1), lingual oblique (1.2), occlusal (1.3), and profile (1.4) views. 2, MSC 35078, partial lower median tooth, labial (2.1), lingual (2.2), lingual oblique (2.3), occlusal (2.4), and profile (2.5) views. 3, MSC 35055, lower right distal-most lateral tooth, basal (3.1), distal (3.2), labial (3.3), mesial (3.4), and occlusal (3.5) views. 4, MSC 35081, partial median tooth, basal (4.1), labial (4.2), lingual (4.3), lingual oblique (4.4), and profile (4.5) views. 5, MSC 35049, lower median tooth, occlusal view. 6, MSC 35071, partial lower median tooth, lingual oblique (6.1), and profile (6.2) views. 7, MSC 35050, lower median tooth, occlusal view. 8, MSC 35061, upper right distal-most lateral tooth, occlusal (8.1), and basal (8.2) views. 9, MSC 12776, upper right distal-most lateral tooth, basal (9.1), labial (9.2), lingual oblique (9.3), occlusal (9.4), distal (9.5), and mesial (9.6) views. 10, MSC 35080, partial median tooth, lingual (10.1), lingual oblique (10.2), and occlusal (10.3) views. 11, MSC 35056, lower right distal-most lateral tooth, distal (11.1), labial (11.2), lingual (11.3), mesial (11.4), and occlusal (labial at left) (11.5) views. 12, MSC 35060, upper right distal-most lateral tooth, basal (12.1), labial (12.2), lingual oblique (12.3), occlusal (12.4), mesial (12.5), and distal (12.6) views. 13, MSC 35079, partial lower median tooth, lingual oblique (13.1), and occlusal (13.2) views. 14, MSC 35065, nearly complete lower median tooth, occlusal view. 15, MSC 35052, partial lower median tooth, occlusal view. Scale bars equal $1.0 \mathrm{~cm}$. 
median tooth; MSC 35075, left half of upper median tooth.

Diagnosis. Teeth are larger than those of the type species, Pseudaetobatus casieri. As in P. casieri, upper median teeth fairly straight, whereas lower median teeth are arcuate, both have crowns with rectangular cross sections, angular distal ends and labial/lingual ornamentation of fine vertical ridges; tooth base thick, with sharply oblique labial face and lingual lobes that extend distally past the crown foot. Distal-most lateral teeth differ from $P$. casieri in being less wide, with shorter and less pronounced distal projection, but more sharply basally curved margin. Intermediate lateral tooth morphology is six-sided and nearly symmetrical.

Description. The holotype is arcuate (labial edge convex, lingual edge concave) and measures 3.2 $\mathrm{cm}$ in width (Figure 4.1). Maximum labio-lingual dimension of the occlusal surface (at the middle of the crown) measures $0.7 \mathrm{~cm}$, but each side of the crown tapers slightly distally and terminates at an angular margin (see also Figure 5.2, 5.6-7, 5.13). The crown of this specimen is only $0.2 \mathrm{~cm}$ thick, but other median teeth in the sample (i.e., Figure 5.4 and 5.6) show that the crown can be at least up to $0.4 \mathrm{~cm}$ in thickness. Other specimens have a crown that is nearly indistinguishable from the root, and we attribute these differences in crown height to in vivo wear. In transverse section the crown has an angular, slightly rectangular outline. Preserved ornamentation on the lingual crown face consists of fine wrinkling, and a thick, rounded transverse ridge is located at the crown foot. This ridge extends along the entire lingual edge of the crown, and its profile is enhanced by super- and subjacent parallel furrows. A shallow groove extending along the entire labial face of the tooth delineates the crown from the root. The root is thick (nearly 0.4 $\mathrm{cm}$ ), polyaulocorhizous, and extends conspicuously distally past the crown, with the oblique labial face bearing numerous short transverse furrows that nearly intersect with lamellae located on the flat basal attachment surface. An additional median tooth morphology, represented by specimens like MSC 35058 (Figure 4.5), MSC 35073, and MSC 35074 , differs from the above morphotype only in being straighter (i.e., less arcuate).

Three lateral tooth morphologies are attributed to this species. MSC 35062 (Figure 4.4) has a six-sided, nearly symmetrical crown, with the rather straight sides meeting at sharp angles. The distal side is thin and the distal angle, which still bears some smooth enameloid, curls slightly basally. A second morphology, represented by specimens like MSC 35054 (Figure 4.2; also Figure $5.3,5.11$ ), has a crown that is slightly longer than wide, with an angular mesial margin. The distal margin is unusual in that it curls basally and terminates lingually into a short, pointed projection. This projection varies in length among the available specimens. The mesial part of the occlusal surface is worn (in vivo usage) but the distal part still bears smooth enameloid. The third morphology, characterized by specimens like MSC 35059 (Figure 4.3; also Figure 5.8-9, 5.12), has a crown that is wider than long. The mesial margin is angular, and the mesial three fourths of the occlusal surface is worn (in vivo usage). The remaining portion of the crown curls slightly basally and still bears smooth enameloid. The distal edge is straight and perpendicular to the crown's width, and it terminates lingually into a pointed projection. The development of this projection varies among the three specimens available.

Remarks. With the exception of MSC 35062, the tooth morphologies described above very closely match specimens from Morocco that Cappetta (1986) identified and illustrated as Pseudaetobatus (pl. 3, figs. 9-12; pl. 4, figs. 1-4). According to his positional determinations, MSC 35048 (Figure 4.1) and others like it (Figure 5.5-7, 5.13-15) are lower median teeth, MSC 350658 (Figure 4.5; also Figure 5.1) is an upper median tooth, MSC 35054 (Figure 4.2; also Figure 5.3, 5.11) is a lower lateral tooth at the margin of the dentition, and MSC 35059 (Figure 4.3; also Figure 5.8, 5.12) is an equivalent tooth from the upper dentition. In contrast to MSC 35054 and MSC 35059, the crown morphology of MSC 35062 (Figure 4.4) suggests that this tooth articulated with other teeth on both the mesial and distal sides, and it would therefore represent an intermediate lateral tooth row located between the median tooth row and the distal-most lateral row at the edge of the dentition. This morphology was not identified in the type species, $P$. casieri (Cappetta, 1986), but we associate it with $P$. belli sp. nov. because of its similarity to the other lateral tooth morphologies attributed to this species.

The holotype of Pseudaetobatus belli sp. nov., a lower median tooth, is $20 \%$ larger than equivalent teeth of $P$. casieri illustrated by Cappetta (1986, plate 3 , figure 9 ). In addition, the distal-most lateral teeth of $P$. belli sp. nov. are not as wide as those of $P$. casieri, the distal corner of the crown is not as elongated, but the distal edge is more tightly curled. The intermediate lateral tooth morphology represented by MSC 35602 may not have been 
available to Cappetta (1986) for his description of $P$. casieri, but it was likely present because it has been identified in another new species of Pseudaetobatus from South Carolina.

Stratigraphic and geographic range. Hatchetigbee Formation (NP 11) of eastern Mississippi and southern Alabama; Tallahatta Formation (NP 1213) of southern Alabama.

\section{Pseudaetobatus undulatus sp. nov. Figure 6}

zoobank.org/F5F4BAC2-B808-42F0-AF11-4FD8B8BCD907

Etymology. Species so named for the undulating nature of the lateral teeth.

Hypodigm. SC 2013.38.91 (holotype), upper right distal-most lateral tooth (Figure 6.1); SC 2013.38.84 (paratype), lower median tooth (Figure 6.6); SC 2013.38.86 (paratype), upper median tooth (Figure 6.8); SC 2001.1.5.1 (paratype), lower right distal-most lateral tooth (Figure 6.5); SC 2001.1.5.2 (paratype), intermediate lateral tooth (Figure 6.4).

Type locality. $33.504444 \mathrm{~N},-84.742778 \mathrm{~W}\left(\mathrm{~N} \mathrm{33^{ \circ }}\right.$ 30 ' 16" lat., W $81^{\circ} 44^{\prime} 34^{\prime \prime}$ long.), Aiken, Aiken County, South Carolina.

Type horizon. Dry Branch Formation, approximately $2.0 \mathrm{~m}$ below contact with overlying Tobacco Road Formation.

Additional material. Abandoned clay pit north of the Aiken city limit, 33.624867 N, -81.681713 W; Aiken County, SC; Dry Branch Formation SC 96.97.52, 22 median tooth fragments; SC 96.97.53, lateral tooth. Type locality - SC 2001.1.3, 110 partial median teeth; SC 2001.1.4.1, upper left distal-most lateral tooth (Figure 6.2); SC 2001.1.4.2, lower right distal-most lateral tooth; SC 2001.1.4.3, lateral tooth; SC 2001.1.5.3, 8 lateral teeth; SC 2001.1.6, lateral tooth; SC 2001.1.7, lower left distal-most lateral tooth; SC 2013.38.85, upper median tooth (Figure 6.10); SC 2013.38.87, upper median tooth; SC 2013.38.88, incomplete upper median tooth; SC 2013.38.89, incomplete upper median tooth; SC 2013.38.90, lower median tooth (Figure 6.7); SC 2013.38.92, lower right distal-most lateral tooth; SC 2013.38.93.1, upper right distal-most lateral tooth; SC 2013.38.93.2, upper left distal-most lateral tooth; SC 2013.38.93.3, lower left distal-most lateral tooth (Figure 6.3); SC 2013.38.93.4, two upper distal-most lateral teeth; SC 2013.38.94, 12 lower distal-most lateral teeth; SC 2013.38.95, intermediate lateral tooth; SC 2013.38.96.1, intermediate lateral tooth; SC 2013.38.96.2, intermediate lateral tooth; SC 2013.38.96.3, three intermediate lateral teeth; SC 2013.38.97, 88 partial median teeth.
Diagnosis. Upper and lower tooth morphologies as in Pseudaetobatus casieri and P. belli sp. nov., but smaller in overall size than the latter species. The distal-most lateral teeth are the most diagnostic, and these are distinguished from equivalent teeth of all other Pseudaetobatus species by their sinuous outline in labial/lingual view.

Description. Upper and lower median teeth have a six-sided and very wide but short (labio-lingually) crown. Upper median teeth are rectilinear, with the largest complete tooth (SC 2013.38.85) measuring slightly over $2.2 \mathrm{~cm}$ in width and $0.35 \mathrm{~cm}$ in length (Figure 6.10). Lower median teeth are arcuate (distal ends of teeth curve lingually), and the largest complete specimen (SC 2013.38.84) measures 1.8 $\mathrm{cm}$ in width (slight damage to left corner) and 0.4 $\mathrm{cm}$ in length (Figure 6.6). Some fragments indicate that teeth can attain a slightly larger size. The crowns of median teeth have a rectangular cross section. The labial face may be vertical or slightly inclined lingually, and it is ornamented with fine vertical wrinkles. The lingual face is nearly always vertical and bears fine vertical wrinkling and/or conspicuous rugosities. Mesial and distal margins of the crown are angular (Figure 6.7-8). A thick, rounded lingual transverse ridge at the crown foot extends along the entire width of the tooth. The ridge profile is enhanced by parallel furrows immediately above and below, and the superjacent furrow is deeply impressed. A shallow groove extending along the entire labial face represents the juncture between the crown and the root. The root is polyaulocorhizous and extends distally past the crown, with the very oblique labial face bearing numerous short transverse furrows that nearly intersect with lamellae located on the flat basal attachment surface.

We associate three lateral tooth morphotypes with the median teeth described above based on crown ornamentation, nature of the lingual longitudinal ridge, and root morphology. The three morphologies are equivalent to those described for Pseudaetobatus belli sp. nov., including upper and lower distal-most laterals, and intermediate lateral. The intermediate lateral teeth have a six-sided crown that is slightly asymmetrical, and straight margins meet at sharp angles (Figure 6.4). The upper and lower distal-most lateral tooth types are similar to those of $P$. casieri and $P$. belli sp. nov., with presumed uppers (Figure 6.1-2) being wider than the lowers (Figure 6.3, 6.5), and the mesial margin being angular but the distal margin being drawn out into a pointed, lingually directed projection. The crowns of $P$. undulatus sp. nov. are sinu- 


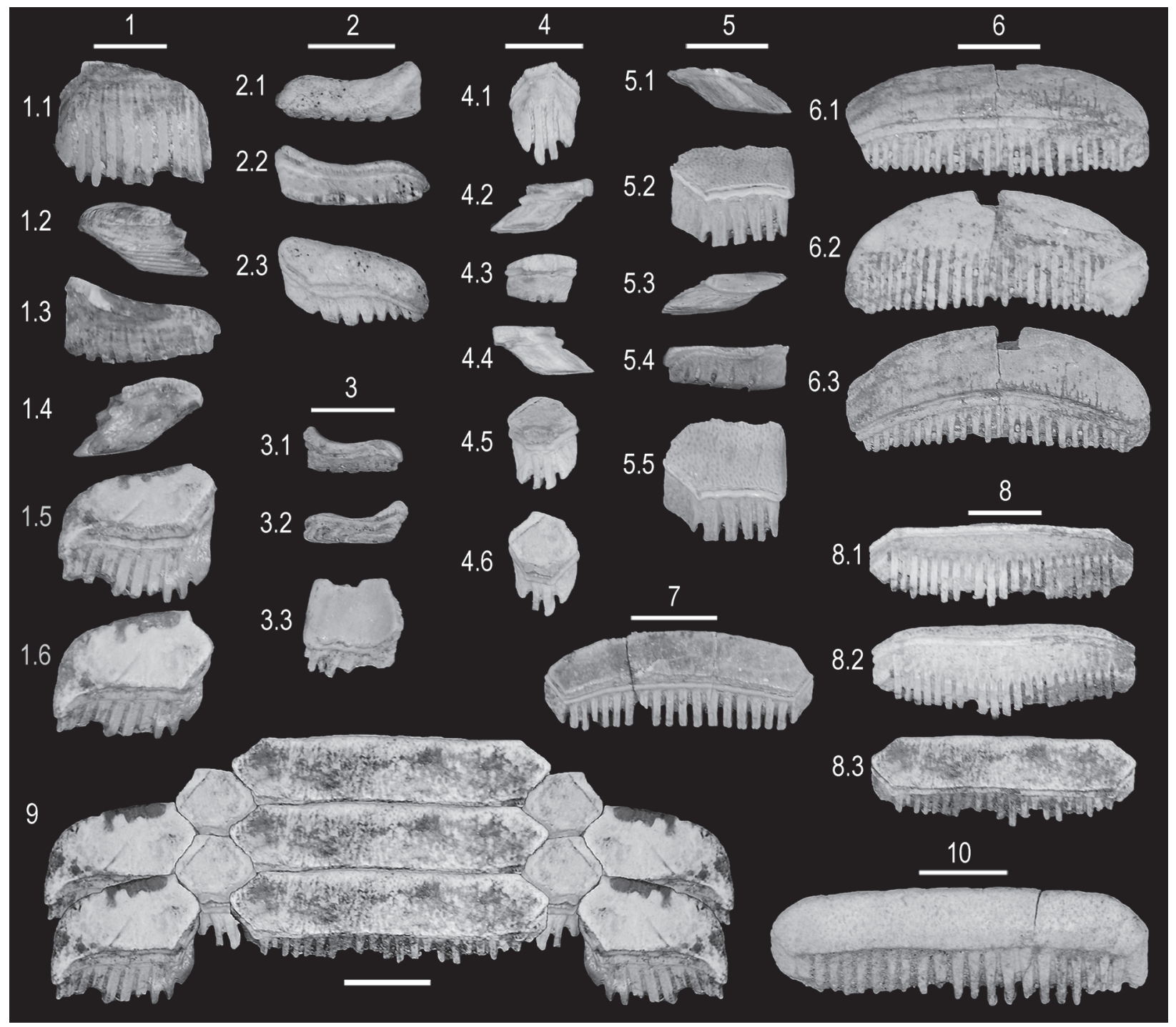

FIGURE 6. Pseudaetobatus undulatus sp. nov. hypodigm and other specimens from the upper Eocene Dry Branch Formation, Aiken County, South Carolina. 1, SC 2013.38.91, upper right distal-most lateral tooth (holotype), basal (1.1), distal (1.2), labial (1.3), mesial (1.4), lingual oblique (1.5), and occlusal (1.6) views. 2, SC 2001.1.4.1, upper left distal-most lateral tooth, labial (2.1), lingual (2.2), and occlusal (2.3) views. 3, SC 2013.38.93.3, lower left distal-most lateral tooth, labial (3.1), lingual (3.2), and occlusal (3.3) views. 4, SC 2001.1.5.2, intermediate lateral tooth (paratype), basal (4.1), distal (4.2), labial (4.3), mesial (4.4), lingual oblique (4.5), and occlusal (4.6) views. 5, SC 2001.1.5.1 (paratype), lower right distal-most lateral tooth, mesial (5.1), lingual oblique (5.2), distal (5.3), labial (5.4), and occlusal (5.5) views. 6, SC 2013.38.84, lower median tooth (paratype), lingual oblique (6.1), basal (6.2), and occlusal (6.3) views. 7, SC 2013.38.90, lower median tooth, lingual oblique view. 8, SC 2013.38.86, upper median tooth (paratype), lingual oblique (8.1), baso-lingual (8.2), and occlusal (8.3) views. 9, Occlusal view of hypothetical reconstruction of part of the upper dentition. This consists of specimens shown in 1 (SC 2001.1.5.2), and 8 (SC 2013.38.86. 1 and 4 were reduced in size to be consistent with 8 , and they were reversed to also represent the right tooth rows. The resulting composite series was then replicated. 10, SC 2013.38.85, upper median tooth, occlusal view. Scale bars equal $0.5 \mathrm{~cm}$.

ous in labial/lingual view due to median concavity and basal curling of the distal margin (Figures 6.1.3, 2.1-2, 3.1-2).

Remarks. The median teeth of Pseudaetobatus undulatus sp. nov. differ from those of $P$. belli $\mathrm{sp}$. nov. in that they are smaller in overall size (SC 2013.38.84 is only half as large as the P. belli holotype), the lingual crown face is more vertical, and the groove above the lingual longitudinal ridge is more deeply impressed. The distal-most lateral 
teeth of $P$. undulatus sp. nov., uppers and lowers, are easily distinguished from $P$. casieri and $P$. belli $\mathrm{sp}$. nov. in having undulating crowns (those of the latter two species are rather flat). In addition, the distal-most lateral teeth of $P$. casieri are wider and have more elongated disto-lingual projections than either $P$. belli sp. nov. or $P$. undulatus sp. nov. (Cappetta, 1986).

Stratigraphic and geographic range. The species is thus far only known from the upper Eocene (Priabonian) Dry Branch Formation of Aiken County, South Carolina.

\section{DISCUSSION}

The taxonomic placement of the teeth that Cappetta (1986) called Pseudaetobatus has recently been brought into question by Hovestadt and Hovestadt-Euler (2013). Their comparison of fossil myliobatid dental remains with those of extant taxa led them to synonymize the Pseudaetobatus median tooth morphology with the genus Pteromylaeus (p. 43). However, they retained the name Pseudaetobatus casieri, restricting its usage to the teeth Cappetta (1986) considered to represent lateral teeth, and they concluded that this latter morphology was unusual enough that Pseudaetobatus could not be confidently assigned to any known myliobatiform group (p. 46, 51). Although Hovestadt and Hovestadt-Euler (2013) have demonstrated that median teeth called Pseudaetobatus superficially resemble those of extant Pteromylaeus (see dentitions they show in plate 12), it appears that they incorrectly presumed that the specimens identified by Cappetta (1986) as Pseudaetobatus lateral teeth (distal-most laterals herein) were broken median teeth. Our samples from Alabama and South Carolina clearly show that Pseudaetobatus sensu Hovestadt and Hovestadt-Euler (2013) represent complete teeth, and that said teeth are conspecific with median teeth they would identify as Pteromylaeus (based on the nature of the crown ornamentation, lingual longitudinal ridge, and root shape). This association leads us to conclude that Pseudaetobatus is a valid genus that the $P$. casieri morphology (and the two new species proposed herein) can be correctly assigned to, and the taxon can be placed within, Myliobatidae.

Recent studies of extant myliobatid rays have elucidated the distinguishing morphological dental features, and the fossil record of species like Aetomylaeus appears to be longer than previously recognized (Herman et al., 2000; Cappetta, 2012; Hovestadt and Hovestadt-Euler, 2013). It is inter- esting to note that the strata yielding Pseudaetobatus belli sp. nov. and $P$. undulatus sp. nov. also contain teeth of the myliobatiform rays Rhinoptera sp. and Aetomylaeus sp., but each taxon can be readily differentiated, even from partial specimens. The teeth of Rhinoptera sp. have a much thicker crown (square cross section) than Pseudaetobatus (rectangular cross section), and the vertical labial and lingual faces bear very fine to coarse longitudinal wrinkles that may be overprinted with fine granulation (Figure 7.1-2). The tooth base of Rhinoptera $\mathrm{sp}$. is also very thin, its labial face is vertical, and it generally does not extend lingually past the crown foot. Although teeth of Aetomylaeus sp. from the Dry Branch Formation (Figure 7.5) have rather thick bases that extend lingually a short distance past the crown, they can be differentiated from Pseudaetobatus in having much thicker crowns that appear slightly rhomboid in cross section. In addition, the weakly concave labial face has a coarse reticulated ornamentation (of interconnected ridges and deep pits), and the weakly convex lingual face is heavily tuberculated. Also, the lingual longitudinal ridge at the crown foot is very thin and sharp, as opposed to thick and rounded on Pseudaetobatus. Teeth from the Tallahatta Formation (Figure 7.4) have a tuberculated labial face and pitted lingual face, and the lingual transverse ridge is thick and rounded. This morphotype could be attributed to Pteromylaeus (i.e., Cappetta, 2012; Hovestadt and Hovestadt-Euler, 2013), but this genus was recently synonymized with Aetomylaeus by White (2014).

The distal ends of Pseudaetobatus median teeth are angular and have straight edges (i.e., Figures $4.1,5.7-8)$, and these areas articulate with lateral teeth. In contrast, Aetobatus has no lateral teeth, the distal ends of median teeth curl basally (Figure 7.8), and the straight margin is perpendicular to the tooth width (see also Hovestadt and Hovestadt-Euler, 2013; Purdy et al., 2001). In Pseudaetobatus, these features are observed on the distal-most lateral teeth (i.e., Figures 4.2-3, 5.3, 5.10). It may be difficult to distinguish these two genera if the distal ends of a median tooth are missing (Figure 5.10; also compare Figure 7.7 to Figure 5.14-15), and the presence of Pseudaetobatus in other deposits could go unnoticed without the aid of more complete material and/or the recognition of lateral teeth.

Cappetta's (1986) interpretations of Pseudaetobatus tooth position were largely based on the dentitions of Aetobatus, in which the upper teeth are rather straight and the lower teeth are arcuate. 


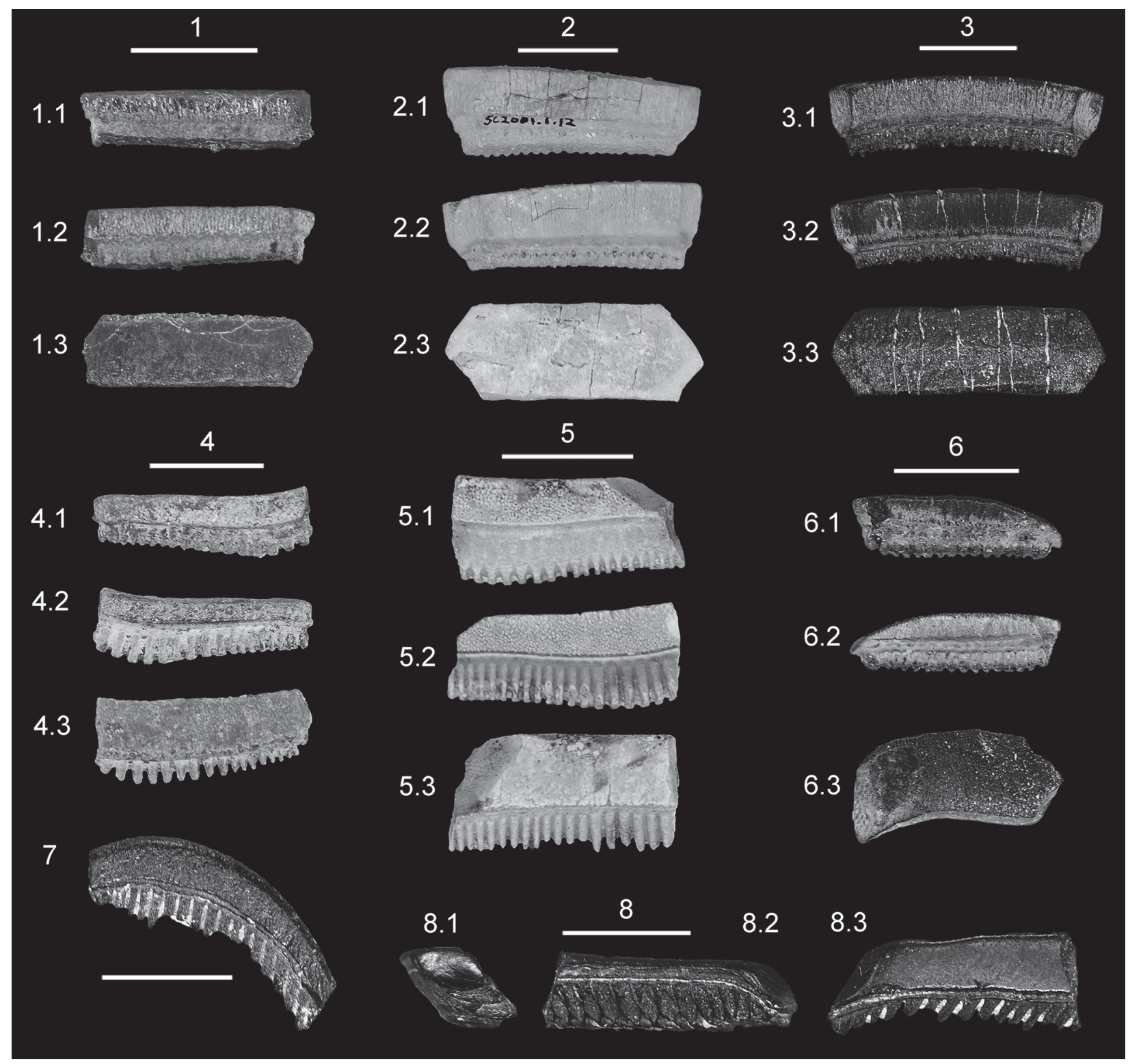

FIGURE 7. Myliobatiform ray teeth associated with Pseudaetobatus in Alabama and South Carolina, comparative specimens of Aetobatus irregularis from Alabama, and late Eocene Rhinoptera sp. from Georgia. 1, Rhinoptera sp. (Tallahatta Formation), MSC 33915, incomplete median tooth, labial (1.1), lingual (1.2), and occlusal (1.3) views. 2, Rhinoptera sp. (Dry Branch Formation), SC 2001.1.12, lateral tooth, labial (2.1), lingual (2.2), and occlusal (2.3) views. 3, Rhinoptera sp. (Clinchfield Formation), SC 2013.44.8, lateral tooth, labial (3.1), lingual (3.2), and occlusal (3.3) views. 4, Aetomylaeus sp. (Tallahatta Formation), MSC 33931, incomplete lower median tooth, labial (4.1), lingual (4.2), and occlusal (4.3) views. 5, Aetomylaeus sp. (Dry Branch Formation), SC 2001.1, incomplete lower median tooth, labial (5.1), lingual (5.2), and occlusal (5.3) views. 6, Rhinoptera sp. (Clinchfield Formation), SC 2013.44.9, distal-most lateral tooth similar to Pseudaetobatus sp., labial (6.1), lingual (6.2), and occlusal (6.3) views. 7-8, Aetobatus irregularis (Lisbon Formation). 7, SC 2012.47.24, incomplete lower median tooth, occlusal view. 8, SC 2012.47.26, left side of upper? median tooth, distal (8.1), labial (8.2), and occlusal (8.3) views. Scale bars equal 1.0 $\mathrm{cm}$.

Hovestadt and Hovestadt-Euler (2013) have shown that even upper median teeth of some extant myliobatid taxa, particularly Pteromylaeus (= Aetomylaeus), can be at least weakly arcuate. This fact may bring into question our ability to confidently attribute all such teeth of Pseudaetobatus to the lower dentition. However, because the lower median teeth of both Aetomylaeus and Aetobatus 
are more obviously curved, we follow Cappetta (1986) when differentiating upper and lower median teeth of Pseudaetobatus. We presume that the upper and lower dentitions within an individual Pseudaetobatus were of equal width based on our observations of two specimens in the SC collection. The upper and lower dentitions of a Rhinoptera bonasus (SC 88.120.1) were of nearly identical width (upper $=7.21 \mathrm{~cm}$, lower $=7.17 \mathrm{~cm}$ ), and those of a Myliobatis californicus (uncurated cast) were also virtually the same (upper $=4.20$ $\mathrm{cm}$, lower $=4.23 \mathrm{~cm}$ ). However, whereas the upper and lower median teeth of the $M$. californicus dentitions were the same width (upper $=2.11 \mathrm{~cm}$, lower $=2.09 \mathrm{~cm}$ ), upper median teeth of the $R$. bonasus specimen are wider than the lowers $(3.16 \mathrm{~cm}$ vs. $2.43 \mathrm{~cm}$ ). This difference in width is compensated for in the lower dentition by the formation of one or more rows of lateral teeth that are wider than those in the upper dentition. Perhaps, then, the shorter distal-most lateral teeth that Cappetta (1986) attributed to the lower dentition were actually part of the upper dentition, and conversely the wider distal-most laterals were part of the lower dentition (not the upper as originally proposed). There is a considerable amount of intra-specific variation in extant myliobatid rays (i.e., figure 11 of Hovestadt and Hovestadt-Euler, 2013), and we cannot know with certainty the correct location of the distal-most laterals or the exact number of intermediate lateral tooth rows without the aid of more complete material. Cappetta (1986) illustrates two articulated lower median teeth (plate 3, figure 9), but unfortunately lateral teeth are not preserved.

Published accounts of the temporal and geographic distribution of Pseudaetobatus casieri have been restricted to the lower Eocene (Ypresian) of Morocco (Cappetta, 1986; Noubhani and Cappetta, 1997). However, Darteville and Casier (1959) identified a specimen from middle Eocene strata of Angola as an abnormal tooth of Aetobatus irregularis, but Cappetta (1986) incontestably referred this tooth to Pseudaetobatus. Duthiel (1991) listed Pseudaetobatus as occurring in the middle-to-late Eocene of France, but these records have yet to be corroborated. This tooth (plate 35 , figure 5 ) is a distal-most lateral tooth, and Darteville and Casier (1959) illustrated an additional specimen (plate 35, figure 3 ) that we consider to be an intermediate lateral tooth of Pseudaetobatus. The occurrence of Pseudaetobatus in the southeastern United States significantly expands the paleogeographic distribution of the genus, and the South Carolina sample allows us to extend the temporal range of the genus is into the late Eocene. Specimens from the Hatchetigbee Formation (NP 11) of Alabama and Mississippi demonstrate that Pseudaetobatus was established in the Western Hemisphere by 53 m.y.a. (Gradstein et al., 2004), with progressively younger occurrences within the overlying "Meridian Sand equivalent" beds at the base of the Tallahatta Formation (NP 12) and the type stratum slightly higher in the formation (NP 13). We presently have no evidence of Pseudaetobatus in middle or upper Eocene deposits of Alabama or Mississippi, but Aetobatus is certainly present within the basal part of the middle Eocene (Lutetian, NP 15) Lisbon Formation (Figure 7.7-8; also Clayton et al., 2013).

Interestingly, the upper Eocene Clinchfield Formation, which is stratigraphically below the Dry Branch Formation in South Carolina and Georgia, has yielded thousands of teeth of Myliobatidae at a site in central Georgia [see Parmley and Cicimurri (2003) for a discussion on fossil shark species from this location], and a single specimen that resembles a distal-most lateral tooth of Pseudaetobatus has been collected (Figure 7.6). At $1.5 \mathrm{~cm}$ in width, it is much larger than any lateral tooth previously assigned to the genus, and its relatively flat occlusal surface easily allows us to exclude it from $P$. undulatus. At least three species of Myliobatidae occur in the same deposit, including Aetomylaeus sp., Rhinoptera sp. (see discussion above), and Myliobatis sp. (sensu Cappetta, 2012). The tooth bases of Aetomylaeus sp. and Myliobatis sp. are thick, have a very oblique labial face, and lingual lobes that extend past the crown foot. In contrast, the base of the Pseudaetobatus-like tooth is thin, the labial face is vertical, and the lingual lobes do not pass the crown foot. These are all characteristics of Rhinoptera sp. teeth as shown in Figure 7.3. Although the distal end of the Pseudaetobatus-like tooth tapers distally, it does not curl basally like the distal ends of lateral teeth of Pseudaetobatus. Additionally, the Clinchfield sample does not contain a single arcuate median tooth as seen in Pseudaetobatus (and Aetobatus), with all of the teeth instead being straight or having the distal ends directed labially (as opposed to lingually for the other two aforementioned genera). Although multiple interpretations of the Pseudaetobatus-like tooth are possible, we argue that it is an aberrant lateral morphology of Rhinoptera sp. because it lacks a combination of characteristics that are seen on distal-most lateral teeth of Pseudaetobatus (i.e., thick tooth base with oblique labial face and lingually expanded lobes, basally curving distal end of crown). 
Elasmobranch species compositions within strata containing Pseudaetobatus from Alabama, Mississippi, and South Carolina, USA, indicate a connection to the Eocene Tethyan realm. For example, Pseudaetobatus was originally described from the lower Eocene of northern Africa (Cappetta, 1986). Elasmobranchs associated with $P$. belli sp. nov. in the Hatchetigbee Formation include, among others, Coupatezia woutersi, Burnhamia sp., Brachycarcharias lerichei, Striatolamia striata, Abdounia beaugei, and Jacquhermania duponti, species well known from the lower-to-middle Eocene of Europe and northern Africa (i.e., Arambourg, 1952; Cappetta and Nolf, 2005; Casier, 1966; Nolf, 1988; Noubhani and Cappetta, 1997; Van den Eeckhout and De Schutter, 2009). The $P$. belli sp. nov. type stratum (Tallahatta Formation) also includes species such as $A$. beaugei, S. striata, B. lerichei, Burnhamia sp., and Hypolophodon sylvestris, and the poorly preserved elasmobranch sample available to us from the underlying Meridian Sand Member contains S. striata and $B$. lerichei. Additionally, the $P$. undulatus sp. nov. type stratum within the Dry Branch assemblage includes Notorynchus kempi, Hemipristis curvatus, Dasyatis tricuspidatus, and Rhinobatos steurbauti, taxa that have variously been reported from lower-to-upper Eocene deposits of Europe, the Middle East, Africa, and eastern Asia (Cappetta and Nolf, 1981; Case et al., 1996; Case and Cappetta, 1990; Casier, 1946; Dames, 1883; Kemp et al., 1990; Mustafa and Zalmout, 2002; Priem, 1905; Stromer, 1905; Ward, 1979).

\section{CONCLUSIONS}

Pseudaetobatus was previously known from lower and middle Eocene deposits of Africa, and only a single species, $P$. casieri, has been described. However, two new species of Pseudaetobatus were recently identified from Eocene deposits of the United States. Pseudaetobatus belli sp. nov. was recovered from lower Eocene strata of the Hatchetigbee Formation (NP 11) of Alabama and Mississippi, as well as the "Meridian Sand equivalent" beds (NP 12) of the Tallahatta Formation of Alabama, and the type material was derived from higher within the Tallahatta Formation (NP 13). Pseudaetobatus undulatus sp. nov. was collected from the upper Eocene (NP 19/20) Dry Branch Formation of south-central South Carolina. Pseudaetobatus was established in the Mississippi Embayment of North America by 53 m.y.a., and the genus persisted along the Atlantic Coast until at least 34.5 m.y.a.
Additional occurrences of Pseudaetobatus in the United States (and elsewhere) may come to light as familiarity with the taxon increases. For example, a tooth Kent (1999: figure 3.1P) identified as Aetobatus from the Nanjemoy Formation (NP 11 , temporally equivalent to the Hatchetigbee Formation) of Virginia has angular distal margins like Pseudaetobatus. We have not personally examined this specimen, but a closer inspection of this tooth and other Eocene elasmobranch faunas in museum collections, particularly those purportedly containing Aetobatus, is warranted.

\section{ACKNOWLEDGEMENTS}

We wish to thank $\mathrm{B}$. Congdon for donating the collection of fossils included within accession SC 2001.1. We also thank L. Bybell (U.S. Geological Survey, Reston, VA) and S. Ebersole (Geological Survey of Alabama, Tuscaloosa) for examining Tallahatta Formation samples for the presence of nannoplankton and foraminifera, respectively. We would like to express our appreciation to A. Scheffield, K. White, and D. Briedis for the long hours they spent sorting through Dry Branch Formation matrix with a binocular microscope. We also thank J. Fletcher, L. Mancin, and B. McCulla for sorting large samples from the Tallahatta Formation. K., R., and S. Knight, C. Cicimurri, and M. Bruggeman assisted with field collecting specimens from the Dry Branch Formation. This report benefitted from the editorial suggestions of G.L. Stringer (University of Louisiana at Monroe) and an anonymous reviewer.

\section{REFERENCES}

Albin, E.F. 1999. Regional stratigraphic correlation of North American Tektites. Lunar and Planetary Science, 30:1-2.

Albin, E.F. and Wampler, J.M. 1996. New potassiumargon ages for georgiaites and the upper Eocene Dry Branch Formation (Twiggs Clay Member): Inferences about tektite stratigraphic occurrence. Lunar and Planetary Science, 27:5-6.

Arambourg, C. 1952. Les vertébrés fossils des gisements de phosphates (Maroc-Algérie-Tunisie). Notes et Mémoires du Service Géologique du Maroc, 92:1372.

Baum, G.R. and Vail, P.R. 1988. Sequence stratigraphic concepts applied to Paleogene outcrops, Gulf and Atlantic basins, p. 309-327. In Wilgus, C.K., Hastings, B.S., Posamentier, H., van Wagoner, J., Ross, C.A., and Kendall, C.G.S.C. (eds.), Sea Level Change - An Integrated Approach. SEPM (Society for Sedimentary Geology) Special Publications 42. 
Bonaparte, C.L. 1838. Selachorum tabula analytica. Nuovi Annali delle Scienze Naturali, 1(2):195-214.

Bybell, L.M. and Gibson, T.G. 1985. The Eocene Tallahatta Formation of Alabama and Georgia: its lithostratigraphy, biostratigraphy, and bearing on the age of the Claibornian Stage. United States Geological Survey Bulletin, 1615:1-20.

Cappetta, H. 1986. Myliobatidae nouveaux (Neoselachii, Batomorphii) de I'Yprésien des Ouled Abdoun, Maroc. Geologica et Palaeontologica, 20:185-207.

Cappetta, H. 2012. Handbook of Paleoichthyology, vol. 3E: Chondrichthyes.Mesozoic and Cenozoic Elasmobranchii: Teeth. Verlag Dr. Friedrich Pfeil.

Cappetta, H. and Nolf, D. 1981. Les sélaciens de l'Auversien de Ronquerolles (Eocène supérieur du Bassin de Paris). Mededelingen van den Werkgroep voor Tertiaire en Kwartaire Geologie, 18(3):87-107.

Cappetta, H. and Nolf, D. 2005. Révision de quelques Odontaspididae (Neoselachii: Lamniformes) du Paléocène et de l'Eocène du Bassin de la Mer du Nord. Bulletin de I'Institut des Sciences Naturelles de Belgique, Science de la Terre, 75:237-266.

Carter, B.D. 1987. Paleogene echinoid distributions in the Atlantic and Gulf Coastal plains. Palaios, 2:390404.

Case, G.R. and Cappetta, H. 1990. The Eocene selachian fauna from the Fayum Depression in Egypt. Palaeontographica Abteilung A, 212:1-30.

Case, G.R., Udovichenko, N.I., Nessov, L.A., Averianov, A.O., and Borodin, P.D. 1996. A middle Eocene selachian fauna from the White Mountain Formation of the Kizylkum Desert, Uzbekistan, C.I.S. Palaeontographica, Abteilung A, 242(4-6):99-126.

Casier, E. 1946. La faune ichthyologique de I'Ypresien de la Belgique. Memoires de Musée Royal d'Histoire Naturelle de Belgique 104.

Casier, E. 1966. Faune ichthyologique du London Clay. British Museum (Natural History), London, England.

Clayton A.A., Ciampagalio, C.N., and Cicimurri, D.J. 2013. An inquiry into the stratigraphic occurrence of a Claibornian (Eocene) vertebrate fauna from Covington County, Alabama. Bulletin of the Alabama Museum of Natural History, 31(2):60-73.

Compagno, L.J.V. 1973. Interrelationships of living elasmobranchs. Zoological Journal of the Linnean Society, 53(1):15-61.

Dames, W. 1883. Über eine tertiäre Wirbelthierfauna von der westlichen Insel des Birket-el-Qurūn im Fajum (Aegypten). Sitzungsberichte der Königlich Preussischen Akademie der Wissenschaften zu Berlin, 6:129-153.

Darteville, E. and Casier, E. 1959. Les poissons fossils du bas-Congo et des regions Voisines (Part III). Annales du Musée Congo belge, Minéralogique Géologique, Paléontologique, 3(2):257-568.

Dockery, D.T., III, Copeland, C.W., Jr., and Huddlestun, P.F. 1994. Reply to a revision of the Hatchetigbee and Bashi formations. Mississippi Geology, 4(3):1115.
Duthiel, D.B. 1991. A checklist of Neoselachii (Pisces, Chondrichthyes) from the Palaeogene of the Paris Basin, France. Tertiary Research, 13(1):27-36.

Edwards, L.E., Bybell, L.M., Gohn, G.S., and Frederiksen, N.O. 1997. Paleontology and physical stratigraphy of the USGS-Pregnall no. 1 core (DOR-208), Dorchester County, South Carolina. United States Geological Survey Open-File Report 97-145.

Edwards, L.E., Gohn, G.S., Bybell, L.M., Chirico, P.G., Christopher, R.A., Frederiksen, N.O., Prowell, D.C., Self-Trail, J.M., and Weems, R.W. 2000. Supplement to the preliminary stratigraphic database for subsurface sediments of Dorchester County, South Carolina. United States Geological Survey Open-File Report 00-049-B.

Eversull, L.G. 2005. The Twiggs Clay: mineralogy, origin, and industrial properties of an upper Eocene opaline claystone in the coastal plain province of Georgia, U.S. Unpublished PhD Dissertation, Louisiana State University, Baton Rouge, Louisiana.

Falls, W.F. and Prowell, D.C. 2001. Stratigraphy and depositional environments of sediments from five cores from Screven and Burke counties, Georgia. USGS Professional Paper 1603-A.

Gibson, T.G. 1982. Revision of the Hatchetigbee and Bashi formations (lower Eocene) in the eastern Gulf Coastal Plain. United States Geological Survey Bulletin, 1529-H:H33-H41.

Gradstein, F., Ogg, J., and Smith, A. 2004. A Geologic Time Scale. Cambridge University Press, Massachusetts.

Harris, R.S., Duncan, M.S., Holland, S.M., Roden, M.F., and Schroeder, P.A. 2002. Probable shocked quartz as evidence for an upper Eocene impact horizon in coastal plain strata, Warren County, Georgia, U.S.A. Geological Society of America, abstracts with programs, 2002 annual meeting, paper 178-9.

Herman, J., Hovestadt-Euler, M., Hovestadt, D.C., and Stehman, M. 2000. Contributions to the study of the comparative morphology of teeth and other relevant ichthyodorulites in living supraspecific taxa of Chondrichthyan fishes. Part B: Batomorphii 4c: Order Rajiformes - Suborder Myliobatoidei - Superfamily Dasyatoidea - Family Dasyatidae - Subfamily Dasyatinae - Genus: Urobatis, Subfamily Potamotrygoninae - Genus:Paratrygon, Superfamiliy Plesiobatoidea - Family Plesiobatidae - Genus: Plesiobatis, Superfamily Myliobatoidea - Family Myliobatidae Subfamily Myliobatinae - Genera: Aetobatus, Aetomylaeus, Myliobatis and Pteromylaeus, Subfamily Rhinopterinae - Genus: Rhinoptera and Subfamily Mobulinae - Genera: Manta and Mobula. Addendum 1 to 4a: erratum to Genus Pteroplatytrygon. Bulletin de l'Institut Royal des Sciences Naturelles de Belgique, 70:5-67. 
Hovestadt, D.C. and Hovestadt-Euler, M. 2013. Generic assessment and reallocation of Cenozoic Myliobatinae based on new information of tooth, tooth plate and caudal spine morphology of extant taxa. Palaeontos 24.

Huddleston, P.F. 1982. The development of the stratigraphic terminology of the Claibornian and Jacksonian marine deposits of western South Carolina and eastern Georgia, p. 21-33. In Nystrom, Jr., P.G. and Willoughby, R.H. (eds.), Geological investigations related to the stratigraphy in the kaolin mining district, Aiken County, South Carolina. Carolina Geological Society, Field Trip Guidebook.

Huddleston, P.F. 1993. A revision of the lithostratigraphic units of the Coastal Plain of Georgia: the Oligocene. Georgia Geologic Survey Bulletin 105.

Huddleston, P.F. and Hetrick, J.H. 1979. The stratigraphy of the Barnwell Group of Georgia. Georgia Geologic Survey, $14^{\text {th }}$ Annual Field Trip of the Georgia Geological Society.

Huddleston, P.F. and Hetrick, J.H. 1986. Upper Eocene stratigraphy of central and eastern Georgia. Bulletin of the Georgia Geologic Survey 95.

Huxley, T.H. 1880. On the application of the laws of evolution to the arrangement of the Vertebrata, and more particularly of the Mammalia. Proceedings of the Zoological Society of London, 1880:649-662.

Kemp, D.J., Kemp, L., and Ward, D.J. 1990. An illustrated guide to the British middle Eocene vertebrates. Privately published.

Kent, B.W. 1999. Rays from the Fisher/Sullivan Site, p. 39-51. In Weems, R.E. (ed.), Fossil vertebrates and plants from the Fisher/Sullivan site (Stafford County): A record of Early Eocene life in Virginia. Virginia Division of Mineral Resources 152.

Mancini, E.A. 2008. Paleogene lowstand systems tract sand deposits of the Eastern Gulf Coastal Plain: potential reservoir facies in the offshore Northeastern Gulf of Mexico. Gulf Coast Association of Geological Societies Transactions, 58:669-675.

Mancini, E.A. and Tew, B.H. 1990. Tertiary sequence stratigraphy and biostratigraphy of southwestern Alabama. A Guidebook for Field Trip 1, 39th Annual Meeting, Southeastern Section, Geological Society of America. Geological Survey of Alabama.

Mancini, E.A. and Tew, B.H. 1991. Relationships of the Paleogene stage and planktonic foraminiferal zone boundaries to lithostratigraphic and allostratigraphic contacts in the eastern Gulf Coastal Plain. Journal of Foraminiferal Research 1:48-66.

Mancini, E.A. and Tew, B.H. 1995. Geochronology, biostratigraphy and sequence stratigraphy of a marginal marine to marine shelf stratigraphic succession: upper Paleogene and lower Eocene, Wilcox Group, eastern Gulf Coastal Plain, U.S.A. Geochronology Time Scales and Global Stratigraphic Correlation, SEPM Special Publication, 54:281-293.
Mittwede, S.K. 1982. Stratigraphy of the Jackson area, Aiken County, South Carolina, p. 65-78. In Nystrom, Jr., P.G. and Willoughby, R.H. (eds.), Geological investigations related to the stratigraphy in the kaolin mining district, Aiken County, South Carolina. Carolina Geological Society, Field Trip Guidebook.

Mustafa, H. and Zalmout, I.S. 2002. Elasmobranchs from the late Eocene Wadi Esh-Shallala Formation of Qa'Faydat ad Dahikiya, east Jordan. Tertiary Research, 21:1-18.

Nolf, D. 1988. Fossiles de Belgique. Dents de requins et de raies du Tertiaire de la Belgique. Institut royal des Sciences naturelles de Belgique, Bruxelles.

Noubhani, A. and Cappetta, H. 1997. Les Orectolobiformes, Carcharhiniformes et Myliobatiformes (Elasmobranchii, Neoselachii) des Bassins à phosphate du Maroc (Maastrichtien-Lutétien basal): Systématique, biostratigraphie, évolution et dynamique des faunes. Palaeo Ichthyologica, 8:1-326.

Nystrom, P.G., Jr. and Willoughby, R.H. 1982. Cretaceous, Tertiary, and Pleistocene (?) stratigraphy of Hollow Creek and Graniteville quadrangles, Aiken County, South Carolina, p. 80-113. In Nystrom, Jr., P.G. and Willoughby, R.H. (eds.), Geological investigations related to the stratigraphy in the kaolin mining district, Aiken County, South Carolina. Carolina Geological Society, Field Trip Guidebook.

Parmley, D. and Cicimurri, D.J. 2003. Late Eocene sharks of the Hardie Mine local fauna of Wilkinson County, Georgia. Georgia Journal of Science, 61:153-179.

Povenmire, K.I. and Povenmire, H. 2002. Three well documented Georgia tektites from Montgomery, Wheeler, and Twiggs counties, Georgia. Lunar and Planetary Science XXXIII.

Priem, F. 1905. Sur les poissons fossils de l'éocène moyen d'Égypte. Bulletin de la Societé Géologique de France (new series), 5:633-641.

Purdy, R.W., Schneider, V.P., Applegate, S.P., McLellan, J.H., Meyer, R.L., and Slaughter, B.H. 2001. The Neogene sharks, rays, and bony fishes from Lee Creek Mine, Aurora, North Carolina, p. 71-202. In Ray, C.E. and Bohaska, D.J. (eds.), Geology and Paleontology of the Lee Creek Mine, North Carolina, III. Smithsonian Contributions to Paleobiology, 90.

Raymond, D.E., Osborne, W.E., Copeland, C.W., and Neathery, T.L. 1988. Alabama Stratigraphy. Geological Survey of Alabama Circular 140.

Savrda, C.E., Counts, J.W., Bigham, E., and Martin, S. 2010. Ichnology of siliceous facies in the Eocene Tallahatta Formation (Eastern United States Gulf Coastal Plain): implications for depositional conditions, storm processes, and diagenesis. Palaios, 25:642-655. 
Schroeder, P.A., Harris, R.S., Roden, M.F., Duncan, M.S., and Holland, S.M. 2002. X-ray diffraction evidence for shocked quartz in an upper Eocene sand deposit, Warren County, Georgia, U.S.A. Geological Society of America, abstracts with programs, 2002 annual meeting, paper 239-12.

Steele, K.B., Zullo, V.A., and Willoughby, R.H. 1986. Recognition of the Eocene (Jacksonian) Dry Branch Formation as Usserys Bluff, Allendale County, South Carolina. South Carolina Geology, 30(2):71-78.

Stromer, E. 1905. Die fischreste des mittleren und oberen Eocäns von Ägypten. I. Tiel: Selachii, B. Squaloidei und II. Tiel: Teleostomi, A. Ganoidei. Beiträge zur Paläontologie und Geologie ÖsterreichUngarns, 18:163-192.

Toulmin, L.D. 1977. Stratigraphic distribution of Paleocene and Eocene fossils in the eastern Gulf Coast region. Geological Survey of Alabama Monograph 13.

Underwood, C.J., Ward, D.J., King, C., Antar, S.M., Zalmout, I.S., and Gingerich, P.D. 2011. Shark and ray faunas in the Middle and Late Eocene of the Fayum Area, Egypt. Proceedings of the Geologists' Association, 122(1):46-66.
Van den Eeckhout, G. and De Schutter, P. 2009. The elasmobranch fauna of the Lede Sand Formation at Oosterzele (Lutetian, middle Eocene of Belgium). Palaeofocus, 1:1-57.

Ward, D.J. 1979. Additions to the fish fauna of the English Paleogene. 3. A review of the Hexanchid sharks with a description of four new species. Tertiary Research, 2(3):111-129.

Willoughby, R.H., Nystrom, P.G., Jr., Campbell, L.D., and Katuna, M.P. 1999. Cenozoic stratigraphic column of the coastal plain of South Carolina. South Carolina Geological Survey, General Geologic Chart 1.

White, W.T. 2014. A revised generic arrangement for the eagle ray family Myliobatidae, with definitions for the valid genera. Zootaxa, 3860(2):149-166.

Zullo, V.A. and Kite, L.E. 1985. Barnacles of the Jacksonian (upper Eocene Griffins Landing Member, Dry Branch Formation in South Carolina and Georgia. South Carolina Geology, 28(1):1-22. 